\title{
Maternal dietary intake of folate, and vitamins B6 and B12 during pregnancy and risk of childhood brain tumors
}

Authors

Kathryn R. Greenop ${ }^{1}$, Margaret Miller ${ }^{2}$, Nicholas H. de Klerk ${ }^{1}$, Rodney J. Scott ${ }^{3,4,5}$, John Attia $^{4,6}$ Lesley J. Ashton ${ }^{7,8}$, Luciano Dalla-Pozza ${ }^{9}$, Carol Bower ${ }^{1}$, Bruce K. Armstrong ${ }^{10,11}$, Elizabeth Milne ${ }^{1}$ for the Aus-CBT Consortium

\section{Affiliations}

1: Telethon Institute for Child Health Research, University of Western Australia, Perth, Australia

2: Child Health Promotion Research Centre, School of Exercise and Health Sciences, Edith Cowan University, Mount Lawley, Australia.

3. School of Biomedical Sciences and Pharmacy, Faculty of Health, University of Newcastle, Newcastle, Australia.

4. Hunter Medical Research Institute, John Hunter Hospital, Newcastle, Australia.

5. Hunter Area Pathology Service, Hunter New England Health, Newcastle, Australia.

6. School of Medicine and Public Health, Faculty of Health, University of Newcastle, Newcastle, Australia

7. Research Portfolio, University of Sydney, Sydney, Australia 
8. School of Women and Children's Health, Faculty of Medicine, University of New South Wales, Sydney, Australia.

9. Oncology Unit, The Children's Hospital at Westmead, Westmead, Australia.

10. Sydney School of Public Health, University of Sydney, Sydney, Australia

11. Sax Institute, Haymarket, NSW, Australia

Address for Correspondence:

Elizabeth Milne

Telethon Institute for Child Health Research

PO Box 855 West Perth, Western Australia, 6872, Australia

Telephone: +610894897756

Facsimile: +610894897700

Email: $\underline{\text { lizm@ichr.uwa.edu.au }}$ 


\section{ABSTRACT}

Childhood brain tumors (CBT) are the second most common childhood cancers, yet their etiology is largely unknown. We investigated whether maternal gestational intake of folate, vitamin B6 and B12 was associated with CBT risk in a nationwide case-control study conducted 2005-2010. Case children 0-14 years were recruited from all 10 Australian pediatric oncology centers. Control children were recruited by national random digit dialling, frequency matched to cases on age, sex and State of residence. Dietary intake was ascertained using food frequency questionnaires, and adjusted for total energy intake. Data from 293 case and 726 control mothers were analysed using unconditional logistic regression. The odds ratio (OR) for the highest versus lowest tertile of folate intake was 0.70 (95\% CI: 0.48, 1.02). The ORs appeared lower in mothers who drank alcohol during pregnancy (OR 0.45, 95\% CI: 0.22, 0.93), mothers who took folic acid (OR 0.67, 95\% CI: 0.42, 1.06) or B6/B12 supplements (OR $0.51,95 \%$ CI: $0.25,1.06)$ and in children younger than 5 years (OR 0.50, 95\% CI: $0.27,0.93$ ). These findings are consistent with folate's crucial role in maintenance of genomic integrity and DNA methylation. Dietary intake of B6 and B12 was not associated with risk of CBT.

Keywords: child, central nervous system, childhood brain tumors, folate, pregnancy, epidemiological 


\section{INTRODUCTION}

Childhood brain tumors (CBT) are the second-most common type of childhood cancer, and have the highest mortality rate of all childhood cancers (1); however, there are very few known causes. We have previously reported an inverse association between maternal folic acid supplementation in the periconceptional period and CBT risk (2). A protective effect is biologically plausible because of the key role folate plays in DNA synthesis and repair, and gene methylation (3).

Although dietary folate has a different structure from supplemental folic acid, and is less readily absorbed in the human digestive tract $(4,5)$, it is plausible that dietary folate intake may also be inversely associated with risk of CBT. Published findings from four previous studies of gestational dietary folate intake and risk of CBT have been inconsistent; one reported an inverse association with risk of primitive neuroectodermal tumors (PNET) (6), while the other three reported null results for all CBTs (7), medulloblastoma (8) and astrocytic glioma (9). Many other studies have investigated associations between risk of CBT and dietary intake of vegetables, which are a major source of dietary folate. Some have reported inverse associations $(6,9,10)$, while others have reported largely null findings $(7,8$, 11-14). The categories of foods investigated and the methods used to group food items and assign intake levels have varied considerably among studies, making it difficult to validate results and draw firm conclusions.

The Australian Study of Childhood Brain Tumors (Aus-CBT) was a nationwide case-control study conducted between 2005 and 2010 and designed to investigate environmental, dietary and genetic risk factors for CBT. The aim of this analysis was to investigate, in detail, whether maternal dietary intake of folate during pregnancy is inversely associated with risk of CBT. We also explored associations with folate's cofactors in the one-carbon metabolic cycle: vitamins B6 and B12. 


\section{MATERIALS AND METHODS}

\section{Participants and recruitment}

Incident CBT cases were identified through all 10 pediatric oncology centers in Australia. Controls were recruited by national random digit dialling (RDD) and frequency matched to cases in a ratio of approximately 2:1 by age, sex and State of residence. Cases were eligible if they were diagnosed between 2005 and 2010, resident in Australia and had an English speaking biological parent available. Controls matched to CBT cases diagnosed in 2005 and 2006 were originally recruited as controls for our national case-control study of childhood leukemia (Aus-ALL; 2003-2007) using identical recruitment methods (15). Aus-CBT and Aus-ALL were approved by the Human Research Ethics Committees at all participating hospitals.

\section{Data collection}

Mothers completed a general exposure questionnaire (including demographics and questions about alcohol consumption during pregnancy) and a 126-item food frequency questionnaire (FFQ), which was based on the Australian Commonwealth Scientific and Research Organization's FFQ (16), and modified to focus on folate, vitamin B6 and vitamin B12 intakes. Mothers were asked about their diet during the last 6 months of pregnancy to avoid atypical diets due to nausea during the first trimester. For each food type, a standard serve size was given and mothers were asked to list the frequency of consumption and the number of standard serves consumed on eating occasions. Additional information was collected about the usual brands of foods, including those potentially fortified with folic acid. Mothers were also asked to report any vitamin or mineral supplements taken in the 3 months before the index pregnancy, the first 3 months of the pregnancy and the last 6 months of the pregnancy. Mothers also completed dietary questionnaires for their children. 


\section{Assessment of nutrient intake}

Daily intakes of dietary folate, vitamin B6, B12 and energy were quantified using a customized computer program that merged data from Australian food composition databases (AUS-NUT 07 (17) for folate and energy, and NUTTAB 2006 (18) for B6 and B12) with the FFQ serving size and individual frequency of consumption to calculate the sum over all foods. Voluntary fortification of certain food categories with folic acid (for example breakfast cereals, breads, fruit and vegetable juices and yoghurts) was allowed at the time of the study; information about the amount of supplemental folic acid in individual products was collected from manufacturers and supermarkets and added to the analysis program. Dietary folate intake was expressed as Dietary Folate Equivalents (DFE), which allows for the higher bioavailability of folic acid compared with folate naturally contained in foods: DFE $=$ natural folate $+(1.7 \mathrm{x}$ folic acid)(4). Mandatory folic acid fortification of bread-making wheat flour was introduced in Australia in September 2009 (19); only two pregnancies (1 case/1 control) overlapped this period, so no adjustments were made. Use of supplements containing folic acid, vitamin B6 or vitamin B12 was determined based on the labeled ingredients of the preparations taken.

\section{Statistical analysis}

Folate, B6 and B12 values were log transformed to correct right skew. These values were then energy-adjusted using methods described elsewhere (20). Energy-adjusted folate, B6 and B12 values were grouped according to tertiles of intake among controls, with the lowest tertile in each forming the reference group.

Maternal supplement use was coded as 'Any use in the three months before or during pregnancy' vs no use during this time (referent); separate variables were created for 1) folic 
acid and 2) vitamins B6 and/or B12; vitamins B6 and B12 were combined as both were found in almost all products containing either.

Odds ratios (OR) and 95 percent confidence intervals (95\% CI) were estimated for energyadjusted dietary intake of folate, B6 and B12 using unconditional logistic regression in SPSS (IBM SPSS for Windows, Version 20.0, Armonk, NY, IBM Corp, 2011). All models were adjusted for study matching variables: child's age, sex and State of residence. In addition, variables associated with case or control status and control mothers' dietary nutrient intake were included: child's year of birth, child's ethnicity, parental education, maternal age, folate and B6/B12 supplement use, and maternal alcohol intake during the pregnancy. The child's dietary intake of folate, B6 and B12 was also assessed for inclusion in the models. Stratified analyses were undertaken by maternal alcohol consumption, folate and B6/B12 supplement use and age of the child. Effect of dietary nutrient intake was also investigated in the two largest CBT subtypes: low-grade gliomas and embryonal tumors.

\section{RESULTS}

Detailed participation and recruitment outcomes have been previously described (2). In brief, 730 eligible CBT cases diagnosed between 2005 and 2010 were identified, of whom 568 (78\%) were invited to participate by their treating physicians. Of these, 374 (66\% of invited, $51 \%$ of eligible) consented to take part. We identified 3624 eligible controls via random-digit dialing; 2255 of these agreed to participate. In accordance with the study's age and sex frequency matching quotas, 1467 of these were recruited. Of those who consented and were recruited, 293 case mothers and 726 control mothers completed FFQs and provided data on key confounders, and thus were included in the analysis. CBT subtypes were categorized by two pediatric oncologists as previously described (2). 
The distributions of demographic and other variables of interest in participating cases and controls were broadly similar (Table 1). However, higher proportions of cases were male and had a mother aged under 25 years. Controls were more likely to have a parent with a university or college level education and be of European ethnicity, and control mothers were more likely to drink alcohol during pregnancy (Table 1). Our use of 2005 and 2006 leukemia study controls resulted in a higher percentage of controls than cases born between 1998 and 2003; year of birth was included as a covariate in all analyses.

The OR for the highest tertile of maternal dietary folate intake relative to the lowest tertile was $0.70(95 \%$ CI $0.48,1.02)$ (Table 2$)$; in the middle tertile it was $0.96(0.68,1.36)$. Dietary intake of B6 and B12 did not appear to be associated with risk of CBT. Addition of child's dietary intake of these nutrients to the models did not alter the estimates for maternal dietary folate (data not shown).

The ORs for the highest tertile of folate intake were 0.45 (95\% CI 0.22, 0.93) among mothers who drank alcohol during pregnancy (trend p-value=0.03) (Table 3), and $0.86(95 \%$ CI 0.54, 1.38) among those who did not (p-value for interaction 0.34$)$. The ORs for dietary intake of vitamin B6 and B12 did not vary substantially by maternal alcohol consumption (Table 3).

It appeared that the inverse trend with dietary folate intake was stronger if the mother took folic acid or vitamin B6/B12 supplements, although the p-values for interaction were 0.63 and 0.61 respectively; Table 4).

There was also an apparent inverse trend across tertiles of maternal folate intake among children diagnosed before 5 years of age that was not seen for children diagnosed at 5 years or older (p-value for interaction 0.48; Table 5). This variation was not seen for dietary B6 or B12 intake. 
The associations of maternal dietary intake of folate, B6 and B12 with risk of low-grade gliomas and embryonal tumors were similar to those observed for all brain tumors, except for increased ORs for embryonal tumors associated with the second and third tertiles of B12 intake (Supplementary Table 2).

\section{DISCUSSION}

We observed a weak inverse association between maternal dietary folate intake during pregnancy and risk of CBT. This association appeared to be stronger among mothers who consumed alcohol or took supplements during pregnancy, and among children aged younger than 5 at diagnosis, although evidence for interactions was weak. The results for dietary folate were similar for different tumor types. There was little or no evidence of associations between maternal dietary intake of B6 or B12 and risk of CBT, apart from some suggestion of a positive association between maternal B12 intake and risk of embryonal tumors.

Our findings suggesting an inverse association with maternal folate intake during pregnancy are consistent with those of Bunin and colleagues, who reported an OR of $0.24(\mathrm{p} \leq 0.1)$ for the highest vs. lowest quartile of intake for PNET (6); however, these investigators found no association with astrocytoma (OR for fourth vs. first quartile was 1.0: 95\% CI 0.5, 2.1) (9). The authors noted that their 53-item FFQ assessed only 55\% of intake (6). In a subsequent study using a more rigorous 112-item FFQ, the same investigators saw no evidence of an association between maternal dietary folate intake and risk of medulloblastoma/PNET in children aged under 6 years (8). In a fourth study, in which a 100-item FFQ was used, Lubin et al. also reported no association with CBT: the OR for the third vs first tertile was 1.18 (95\% CI: $0.8,1.8)(7)$. The current findings regarding dietary folate are consistent with several previous reports, including our own, of a protective effect of folic acid supplementation $(2,21,22)$. We previously reported an OR of $0.68(95 \%$ CI $0.43,1.09)$ for supplementation over $450 \mathrm{mcg} / \mathrm{day}$ during trimesters $2 / 3$ (reference category: no folic acid 
supplementation before or during pregnancy) (2). The corresponding OR for dietary folate intake of that level would be 0.84 (95\% CI 0.61, 1.15) (data not shown); however, the reference category would include women with at least some dietary folate, so this OR would be biased upward towards the null compared with the OR for supplemental folic acid in the current analysis. Thus, there is evidence that both dietary folate and supplemental folic acid have similarly inverse associations with risk of CBT.

A protective relationship between high maternal folate intake and CBT risk is biologically plausible given that folate is intimately involved in DNA methylation and maintenance of genomic integrity (3). It provides 5-methyltetrahydrofolate for the methylation of homocysteine to methionine, which is converted to S-adenosylmethionine, the principal methyl donor in DNA methylation. DNA methylation affects gene expression, and specific promoter region $\mathrm{CpG}$ methylation can silence cell-cycle-regulating genes. In addition, the folate derivative 5,10-methylenetetrahydrofolate is essential for normal DNA synthesis and repair, as it is the one-carbon donor in the synthesis of thymidylate. Vitamin B6 (B6) and vitamin B12 (B12) are essential cofactors in these one-carbon metabolic pathways (23). Folate insufficiency may result in genetic mutations, aberrant DNA methylation in signaling pathway genes, and activation of oncogenes or inactivation of tumor suppressor genes factors known to be involved in the pathogenesis of at least some CNS tumors (24). Histone lysine methylation, in which folate would be involved as a methyl donor, is thought to play a role in the pathogenesis of medulloblastoma; a recent study using high-resolution SNP genotyping on 212 medulloblastomas identified focal genetic events targeting genes controlling lysine methylation in $19 \%$ of the samples (25). That activity-impairing polymorphisms in folate pathway genes are associated with an increased risk of brain tumors in children (26) and adults (27) adds to the evidence indicating that folate is involved. Interestingly, a reduced risk of other solid tumors in children has been associated with 
maternal folic acid or multivitamin use $(28,29)$, but the responsible micronutrients have not been identified. Two other studies reported a reduced incidence of Wilms' tumour (30) and neuroblastoma (31) following the introduction of folate fortification of flour in Canada.

We found some evidence that the inverse association between dietary folate intake during pregnancy and risk of CBT was stronger among women who consumed alcohol. This is biologically plausible, as alcohol is known to decrease folate absorption from the gut, liver uptake and renal conservation, leading to a reduced serum folate level (32-35). Thus, it is possible that a diet rich in folate is more important for the prevention of CBT when serum folate levels have been reduced through the consumption of alcohol. Consistent with this finding, we have previously reported a stronger inverse association between maternal dietary folate intake and risk of childhood ALL when the mother consumed alcohol during pregnancy (36). In addition, in adults, greater protective effects of folate and folic acid among alcohol drinkers have been seen for breast cancer $(37,38)$, colon cancer $(39)$ and oral cancer in women (40).

Vitamins B6 and B12 are cofactors in the folate metabolic cycle (23). Thus, the suggestion of a stronger inverse association with folate intake among women who took vitamin B6/B12 supplements is consistent with enhanced metabolic cycle activity at higher levels of folate substrate. The elevated OR observed for B12 intake and risk of embryonal tumors is difficult to explain; it could not be explained by intake of animal protein, the main source of vitamin B12, in our study (results not shown). We were unable to find any literature that would support or suggest a mechanism for this association; thus, it is probably a chance finding. Ours is one of the largest studies of maternal folate intake and risk of CBT undertaken to date, and the first to investigate these associations by the child's age at diagnosis and maternal alcohol intake and use of vitamin supplements. We also took account of the child's diet in our analyses, although this had no impact on the results. The quantified FFQ used in this 
study was designed specifically to assess maternal dietary folate intake, and brand names of packaged foods consumed were checked for folic acid fortification. Diet was assessed during the latter half of pregnancy, when folate requirements are highest to accommodate DNA and RNA synthesis, and fetal and maternal tissue growth (41).

Almost $78 \%$ of eligible cases were invited to participate by the treating clinician and $66 \%$ of invited parents consented, resulting in an overall participation fraction of $51 \%$. The distributions of age and sex among non-participants were similar to participating cases; however, no other information about them was available. Thus, we were unable to determine the extent to which our cases were representative of all eligible cases with respect to potential risk factors.

Control families were recruited by national RDD using state-of-the-art methods and, according to the most recent data available, approximately $90 \%$ of Australian households had a landline telephone connection during the recruitment period $(42,43)$. Therefore, residences contacted are likely to be representative of the wider population. Participation among eligible control families was $62 \%$ and, although no individual information was available for those who declined, area-based SES scores were higher among participating controls than among the wider Australian population (2). Although maternal dietary folate intake was not related to area-based SES in our study population, it was related to parental education. Higher education was associated with higher dietary intake of folate and vitamin B6, and lower intake of vitamin B12. More than 50\% of case and control families had at least one parent with a university or college education, compared with $24 \%$ of Australian adults aged 20-44 years (44). Therefore, our participating mothers are likely to have diets higher in folate and B6, and lower in B12, than the general population. As participation was lower among controls than cases, the most likely result of this would be to underestimate ORs for folate and B6, and overestimate those for vitamin B12. However our results were similar for mothers 
with and without a university education (data not shown), suggesting that confounding by selection is unlikely to have had a large impact on our findings.

Due to the dependence on self-reported data, some error in exposure measurement is likely, particularly as the index pregnancy was 15 years earlier for some mothers. However, the recall period was six years or less for over half the participating mothers. In a methodological study of women's recall of diet during a pregnancy 3-7 years in the past (45), moderately good correlations were reported for folate $(\mathrm{rho}=0.30, \mathrm{P}<0.001), \mathrm{B} 6(\mathrm{rho}=0.42, \mathrm{P}<0.0001)$ and $\mathrm{B} 12(\mathrm{rho}=0.62, \mathrm{P}<0.0001)$. As there is little public awareness of a putative association between maternal diet and risk of CBT, any error in reporting is likely to be non-differential between cases and controls and would bias effect estimates to the null.

The possibility that mothers of cases ruminate about the causes of their child's cancer and recall exposure more completely than control mothers is inherent in case-control studies and may introduce recall bias. However, case mothers' enhanced recall of a potentially protective high quality diet would not be expected to produce an inverse association, but it may weaken one. From a mechanistic viewpoint, the somewhat stronger inverse association seen for children diagnosed early in life is consistent with the likely impact of a protective exposure occurring in utero or perinatally.

As we only assessed maternal diet during the last 6 months of pregnancy, we were unable to determine whether folate intake during a particular prenatal period is most important in reducing the risk of $\mathrm{CBT}$; however, previous evidence indicates that maternal diet before and during pregnancy are similar $(46,47)$.

In conclusion, the results of this study provide some evidence that maternal dietary folate intake during pregnancy may reduce the risk of CBT, particularly among mothers who drink alcohol and when combined with supplement use. Our findings support ongoing promotion a 
Greenop 14

diet rich in folate for women throughout pregnancy. This is likely to reduce the risk of a range of adverse health outcomes, including CBT. 


\section{ACKNOWLEGEMENTS}

The Aus-CBT consortium conducted the study and the Telethon Institute for Child Health Research (TICHR), University of Western Australia, was the coordinating center. Bruce Armstrong (Sydney School of Public Health, University of Sydney), Elizabeth Milne, Nicholas de Klerk, Carol Bower, Peter Dallas (TICHR), Frank van Bockxmeer (Royal Perth Hospital, University of WA), Rodney Scott and John Attia (University of Newcastle), Lin Fritschi (WA Institute for Medical Research), Lesley Ashton, Michelle Haber and Murray Norris (Children's Cancer Institute Australia for Medical Research, Lowy Cancer Research Centre, UNSW), Margaret Miller (Edith Cowan University) and Judith Thompson (WA Cancer Registry) were the research investigators.

The authors acknowledge the contribution made by our clinical co-investigators who recruited and cared for study patients at each participating hospital: Nicholas Gottardo (Princess Margaret Hospital, TICHR); John Heath and Elizabeth Smibert (Royal Children's Hospital, Melbourne); Peter Downie (Monash Medical Centre, Melbourne); Tim Hassall and Ross Pinkerton (Royal Children's Hospital Brisbane); Maria Kirby (Women's and Children's Hospital, Adelaide); Stewart Kellie and Luciano Dalla-Pozza (Westmead Hospital); Frank Alvaro (John Hunter Hospital, Newcastle); Richard Cohn (Sydney Children's Hospital) and John Daubenton (Royal Hobart Hospital).

The authors also acknowledge the Clinical Research Associates at each hospital, the study coordinators: Jackie Mansour, Somer Dawson, Tamika Heiden, and Helen Bailey, and Mr Peter Cosgrove for programming the estimation of dietary intake from the food frequency questionnaires.

Funding: The National Health and Medical Research Council (NHMRC) funded Aus-ALL (Grant number: 254539) and Aus-CBT (Grant number: 404089). Elizabeth Milne and Carol 
Greenop 16

Bower were supported by NHMRC Fellowships. Support for Rodney Scott was in part from NBN Children's Cancer Research Fund.

Conflict of Interest Disclosure: The authors declare that they have no conflict of interest. 


\section{REFERENCES}

1. Baldwin RT, Preston-Martin S: Epidemiology of brain tumors in childhood--a review. Toxicol Appl Pharmacol 199,118-131, 2004.

2. Milne E, Greenop KR, Bower C, Miller M, van Bockxmeer FM, Scott RJ, de Klerk NH, Ashton LJ, Gottardo NG, Armstrong BK: Maternal use of folic acid and other supplements and risk of childhood brain tumors. Cancer Epidemiol Biomarkers Prev 21,1933-1941, 2012.

3. Kim Y-I: Folate and carcinogenesis: Evidence, mechanisms, and implications. J Nutr Biochem 10,66-88, 1999.

4. Bailey LB: Dietary reference intakes for folate: the debut of dietary folate equivalents. Nutr Rev 56,294-299, 1998.

5. Sauer J, Mason JB, Choi SW: Too much folate: a risk factor for cancer and cardiovascular disease? Curr Opin Clin Nutr Metab Care 12,30-36, 2009.

6. Bunin GR, Kuijten RR, Buckley JD, Rorke LB, Meadows AT: Relation between maternal diet and subsequent primitive neuroectodermal brain tumors in young children. $N$ Engl J Med 329,536-541, 1993.

7. Lubin F, Farbstein H, Chetrit A, Farbstein M, Freedman L, Alfandary E, Modan B: The role of nutritional habits during gestation and child life in pediatric brain tumor etiology. Int J Cancer 86,139-143, 2000.

8. Bunin GR, Kushi LH, Gallagher PR, Rorke-Adams LB, McBride ML, Cnaan A: Maternal Diet During Pregnancy and its Association with Medulloblastoma in Children: A Children's Oncology Group Study (United States). Cancer Causes Control 16,877$891,2005$.

9. Bunin GR, Kuijten RR, Boesel CP, Buckley JD, Meadows AT: Maternal diet and risk of astrocytic glioma in children: a report from the Childrens Cancer Group (United States and Canada). Cancer Causes Control 5,177-187, 1994.

10. McCredie M, Maisonneuve P, Boyle P: Antenatal risk factors for malignant brain tumours in New South Wales children. Int J Cancer 56,6-10, 1994.

11. Pogoda JM, Preston-Martin S, Howe G, Lubin F, Mueller BA, Holly EA, Filippini G, Peris-Bonet R, McCredie MR, Cordier S, Choi W: An international case-control study of maternal diet during pregnancy and childhood brain tumor risk: a histology-specific analysis by food group. Ann Epidemiol 19,148-160, 2009. 
12. Preston-Martin S, Pogoda JM, Mueller BA, Holly EA, Lijinsky W, Davis RL: Maternal consumption of cured meats and vitamins in relation to pediatric brain tumors. Cancer Epidemiol Biomarkers Prev 5,599-605, 1996.

13. Cordier S, Iglesias MJ, Le Goaster C, Guyot MM, Mandereau L, Hemon D: Incidence and risk factors for childhood brain tumors in the Ile de France. Int J Cancer 59,776-782, 1994.

14. Preston-Martin S, Yu MC, Benton B, Henderson BE: N-Nitroso Compounds and Childhood Brain Tumors: A Case-Control Study. Cancer Res 42,5240-5245, 1982.

15. Bailey H, Milne E, de Klerk N, Fritschi L, Bower C, Attia J, Armstrong B:

Representativeness of child controls recruited by random digit dialing. Paediatr Perinat Epidemiol 24,293-302, 2010.

16. Lassale C, Guilbert C, Keogh J, Syrette J, Lange K, Cox DN: Estimating food intakes in Australia: validation of the Commonwealth Scientific and Industrial Research Organisation (CSIRO) food frequency questionnaire against weighed dietary intakes. $J$ Hum Nutr Diet 22,559-566, 2009.

17. Food Standards Australia New Zealand: AUSNUT 2007 - Australian food, supplement and nutrient database for estimation of population nutrient intakes. Canberra: FSANZ, 2008 .

18. Food Standards Australia New Zealand: NUTTAB 2010 - Australian Food Composition Tables. Canberra: FSANZ, 2011.

19. Australia New Zealand Food Standards Code - Standard 2.1.1 - Cereals and Cereal Products - F2009C00811, Amendment No. 111 - 2009 Canberra [http://www.comlaw.gov.au/Details/F2009C00811p]: Commonwealth of Australia 2009.

20. Willett W, Stampfer MJ: Total energy-intake - implications for epidemiologic analyses. Am J Epidemiol 124,17-27, 1986.

21. Preston-Martin S, Pogoda JM, Mueller BA, Lubin F, Holly EA, Filippini G, Cordier S, Peris-Bonet R, Choi W, Little J, Arslan A: Prenatal vitamin supplementation and risk of childhood brain tumors. Int J Cancer 11,17-22, 1998.

22. Stålberg K, Haglund B, Strömberg B, Kieler H: Prenatal exposure to medicines and the risk of childhood brain tumor. Cancer Epidemiol 34,400-404, 2010.

23. Selhub J: Folate, vitamin B12 and vitamin B6 and one carbon metabolism. J Nutr Health Aging 6,39-42, 2002. 
24. Gurney JG, Smith MA, Olshan AF, Hecht SS, Kasum CM: Clues to the etiology of childhood brain cancer: N-nitroso compounds, polyomaviruses, and other factors of interest. Cancer Invest 19,630-640, 2001.

25. Northcott PA, Nakahara Y, Wu X, Feuk L, Ellison DW, Croul S, Mack S, Kongkham PN, Peacock J, Dubuc A, Ra YS, Zilberberg K, et al.: Multiple recurrent genetic events converge on control of histone lysine methylation in medulloblastoma. Nat Genet 41,465-472, 2009.

26. Sirachainan N, Wongruangsri S, Kajanachumpol S, Pakakasama S, Visudtibhan A, Nuchprayoon I, Lusawat A, Phudhicharoenrat S, Shuangshoti S, Hongeng S: Folate pathway genetic polymorphisms and susceptibility of central nervous system tumors in Thai children. Cancer Detect Prev 32,72-78, 2008.

27. Bethke L, Webb E, Murray A, Schoemaker M, Feychting M, Lonn S, Ahlbom A, Malmer B, Henriksson R, Auvinen A, Kiuru A, Salminen T, et al.: Functional polymorphisms in folate metabolism genes influence the risk of meningioma and glioma. Cancer Epidemiol Biomarkers Prev 17,1195-1202, 2008.

28. Schuz J, Weihkopf T, Kaatsch P: Medication use during pregnancy and the risk of childhood cancer in the offspring. Eur J Pediatr 166,433-441, 2007.

29. Olshan AF, Smith JC, Bondy ML, Neglia JP, Pollock BH: Maternal vitamin use and reduced risk of neuroblastoma. Epidemiology 13,575-580, 2002.

30. Grupp SG, Greenberg ML, Ray JG, Busto U, Lanctôt KL, Nulman I, Koren G: Pediatric cancer rates after universal folic acid flour fortification in Ontario. J Clin Pharmacol 51,60-65, 2011.

31. French AE, Grant R, Weitzman S, Ray JG, Vermeulen MJ, Sung L, Greenberg M, Koren G: Folic acid food fortification is associated with a decline in neuroblastoma. Clin Pharmacol Ther 74,288-294, 2003.

32. Halsted CH, Villanueva JA, Devlin AM, Chandler CJ: Metabolic interactions of alcohol and folate. J Nutr 132,2367S-2372S, 2002.

33. Lieber CS: Alcohol: its metabolism and interaction with nutrients. Annu Rev Nutr 20,395430, 2000.

34. Laufer EM, Hartman TJ, Baer DJ, Gunter EW, Dorgan JF, Campbell WS, Clevidence BA, Brown ED, Albanes D, Judd JT, Taylor PR: Effects of moderate alcohol consumption on folate and vitamin B(12) status in postmenopausal women. Eur J Clin Nutr 58,1518-1524, 2004. 
35. van der Gaag MS, Ubbink JB, Sillanaukee P, Nikkari S, Hendriks HF: Effect of consumption of red wine, spirits, and beer on serum homocysteine. Lancet 355,1522, 2000 .

36. Bailey HD, Miller M, Langridge A, de Klerk NH, van Bockxmeer FM, Attia J, Scott RJ, Armstrong BK, Milne E: Maternal dietary intake of folate and vitamins b6 and B12 during pregnancy and the risk of childhood acute lymphoblastic leukemia. Nutr Cancer 64,1122-1130, 2012.

37. Zhang S, Hunter DJ, Hankinson SE, Giovannucci EL, Rosner BA, Colditz GA, Speizer FE, Willett WC: A prospective study of folate intake and the risk of breast cancer. JAMA 281,1632-1637, 1999.

38. Islam T, Ito H, Sueta A, Hosono S, Hirose K, Watanabe M, Iwata H, Tajima K, Tanaka H, Matsuo K: Alcohol and dietary folate intake and the risk of breast cancer: a casecontrol study in Japan. Eur J Cancer Prev 22,358-366, 2013.

39. Giovannucci E, Stampfer MJ, Colditz GA, Rimm EB, Trichopoulos D, Rosner BA, Speizer FE, Willett WC: Folate, methionine, and alcohol intake and risk of colorectal adenoma. J Natl Cancer Inst 85,875-884, 1993.

40. Shanmugham JR, Zavras AI, Rosner BA, Giovannucci EL: Alcohol-folate interactions in the risk of oral cancer in women: a prospective cohort study. Cancer Epidemiol Biomarkers Prev 19,2516-2524, 2010.

41. Simpson JL, Bailey LB, Pietrzik K, Shane B, Holzgreve W: Micronutrients and women of reproductive potential: required dietary intake and consequences of dietary deficiency or excess. Part I - Folate, Vitamin B12, Vitamin B6. J Matern Fetal Neonatal Med 23,1323-1343, 2010.

42. Australian Bureau of Statistics: Western Australia Statistical Indicators, Sept 2008.Cat. No: 1367.5. Canberra: ABS, Commonwealth of Australia, 2008.

43. Dal Grande E, Taylor AW: Sampling and coverage issues of telephone surveys used for collecting health information in Australia: results from a face-to-face survey from 1999 to 2008. BMC Med Res Methodol 10,77, 2010.

44. Australian Bureau of Statistics: Education and work Australia, May 2007. Canberra: Commonwealth of Australia, 2007.

45. Bunin GR, Gyllstrom ME, Brown JE, Kahn EB, Kushi LH: Recall of diet during a past pregnancy. Am J Epidemiol 154,1136-1142, 2001.

46. McGowan CA, McAuliffe FM: Maternal dietary patterns and associated nutrient intakes during each trimester of pregnancy. Public Health Nutr 16,97-107, 2013. 
47. Cucó G, Fernández-Ballart J, Sala J, Viladrich C, Iranzo R, Vila J, Arija V: Dietary patterns and associated lifestyles in preconception, pregnancy and postpartum. Eur $J$ Clin Nutr 60,364-371, 2006. 
Table 1: Characteristics of cases and controls in the Australian Study of Childhood Brain Tumors

\begin{tabular}{|c|c|c|c|c|c|}
\hline \multirow{2}{*}{ Characteristic } & & \multicolumn{2}{|c|}{ Cases $(n=293)$} & \multicolumn{2}{|c|}{ Controls $(n=726)$} \\
\hline & & $n$ & $\%$ & $n$ & $\%$ \\
\hline \multirow[t]{4}{*}{ Child's age } & $0-1$ & 29 & 9.9 & 84 & 11.6 \\
\hline & $2-4$ & 83 & 28.3 & 234 & 32.2 \\
\hline & $5-9$ & 85 & 29.0 & 220 & 30.3 \\
\hline & $10-15$ & 96 & 32.8 & 188 & 25.9 \\
\hline \multirow[t]{2}{*}{ Child sex } & Female & 120 & 41.0 & 350 & 48.2 \\
\hline & Male & 173 & 59.0 & 376 & 51.8 \\
\hline \multirow[t]{5}{*}{ State of residence ${ }^{a}$} & NSW/ACT & 101 & 34.5 & 215 & 29.6 \\
\hline & Victoria/Tasmania & 82 & 28.0 & 202 & 27.8 \\
\hline & SA/NT & 18 & 6.1 & 58 & 8.0 \\
\hline & WA & 38 & 13.0 & 84 & 11.6 \\
\hline & Queensland & 54 & 18.4 & 167 & 23.0 \\
\hline \multirow[t]{3}{*}{ Child's year of birth } & 1990-1998 & 82 & 28.0 & 175 & 24.1 \\
\hline & $1998-2003$ & 120 & 41.0 & 357 & 49.2 \\
\hline & 2004-2010 & 91 & 31.1 & 194 & 26.7 \\
\hline Mother's age & $<25$ & 44 & 15.0 & 50 & 6.9 \\
\hline \multirow[t]{2}{*}{ at child's birth } & $25-34$ & 184 & 62.8 & 460 & 63.4 \\
\hline & $35+$ & 65 & 22.2 & 216 & 29.8 \\
\hline Best education & $\begin{array}{l}\text { Did not complete } \\
\text { high school }\end{array}$ & 39 & 13.3 & 58 & 8.0 \\
\hline \multirow[t]{2}{*}{ of either parent } & $\begin{array}{l}\text { Completed high } \\
\text { school/trade } \\
\text { qualification }\end{array}$ & 99 & 33.8 & 233 & 32.1 \\
\hline & University/college & 155 & 52.9 & 435 & 59.9 \\
\hline \multirow[t]{4}{*}{ Child's ethnicity ${ }^{\mathrm{b}}$} & European & 181 & 61.8 & 562 & 77.4 \\
\hline & $\begin{array}{l}\text { At least } 50 \% \\
\text { European }\end{array}$ & 70 & 23.9 & 116 & 16.0 \\
\hline & $\begin{array}{l}\text { At least } 50 \% \text { non- } \\
\text { European }\end{array}$ & 12 & 4.1 & 23 & 3.2 \\
\hline & Indeterminate & 30 & 10.2 & 25 & 3.4 \\
\hline Mother consumed & No & 204 & 69.6 & 436 & 60.1 \\
\hline alcohol during pregnancy & Yes & 89 & 30.4 & 290 & 39.9 \\
\hline Mother smoked & No & 243 & 82.9 & 616 & 84.8 \\
\hline during pregnancy & Yes & 50 & 17.1 & 110 & 15.2 \\
\hline
\end{tabular}

${ }^{\mathrm{a} N S W}$ : New South Wales; ACT: Australian Capital Territory; SA: South Australia; NT: Northern Territory; WA: Western Australia

${ }^{\mathrm{b}}$ European: at least 3 European grandparents; 50\% European: 2 European grandparents; at least 50\% non-European: 2 non-European grandparents and ethnicity of 2 other grandparents unknown; indeterminate: no 2 grandparents of same ethnicity (i.e European or non-European) and $2+$ grandparents of unknown ethnicity. 
Table 2: Maternal dietary folate, B6 and B12 during pregnancy and risk of CBT

\begin{tabular}{|c|c|c|c|c|c|c|}
\hline & \multicolumn{2}{|c|}{$\begin{array}{l}\text { Cases } \\
(\mathrm{n}=293)\end{array}$} & \multicolumn{2}{|c|}{$\begin{array}{l}\text { Controls } \\
(\mathrm{n}=726)\end{array}$} & \multirow[b]{2}{*}{$\mathrm{OR}^{\mathrm{a}}$} & \multirow[b]{2}{*}{$95 \% \mathrm{CI}$} \\
\hline & $\mathrm{n}$ & $\%$ & $\mathrm{n}$ & $\%$ & & \\
\hline \multicolumn{7}{|c|}{ Energy-adjusted dietary folate $(\mathrm{mcg})$} \\
\hline$\leq 448.57$ & 115 & 39.2 & 242 & 33.3 & 1.00 & Referent \\
\hline $448.57-561.35$ & 102 & 34.8 & 241 & 33.2 & 0.96 & $0.68,1.36$ \\
\hline$>561.35$ & 76 & 25.9 & 243 & 33.5 & 0.70 & $0.48,1.02$ \\
\hline $\mathrm{P}$ trend & & & & & & 0.07 \\
\hline \multicolumn{7}{|c|}{ Energy-adjusted B6 (mg) } \\
\hline$\leq 1.48$ & 95 & 32.4 & 242 & 33.3 & 1.00 & Referent \\
\hline $1.48-1.68$ & 105 & 35.8 & 242 & 33.3 & 1.13 & $0.80,1.60$ \\
\hline$>1.68$ & 93 & 31.7 & 242 & 33.3 & 1.04 & $0.72,1.50$ \\
\hline $\mathrm{P}$ trend & & & & & & 0.82 \\
\hline \multicolumn{7}{|c|}{ Energy-adjusted B12 (mcg) } \\
\hline$\leq 4.61$ & 88 & 30.0 & 242 & 33.3 & 1.00 & Referent \\
\hline $4.61-5.76$ & 102 & 34.8 & 242 & 33.3 & 1.04 & $0.73,1.50$ \\
\hline$>5.76$ & 103 & 35.2 & 242 & 33.3 & 1.00 & $0.69,1.43$ \\
\hline $\mathrm{P}$ trend & & & & & & 0.99 \\
\hline
\end{tabular}

a Adjusted for matching variables (child's age, sex, State of residence), child's year of birth, best parental education, child's ethnicity, maternal supplementation with folic acid 3 months before or during pregnancy, maternal supplementation with B6/B12 3 months before or during pregnancy, maternal consumption of alcohol during pregnancy. 
Table 3: Maternal dietary folate, B6 and B12 during pregnancy stratified by maternal alcohol consumption during pregnancy and risk of CBT No alcohol during pregnancy Any alcohol during pregnancy

\begin{tabular}{|c|c|c|c|c|c|c|c|c|c|c|c|c|}
\hline & \multirow{2}{*}{\multicolumn{2}{|c|}{$\begin{array}{l}\text { Cases } \\
(\mathrm{n}=204)\end{array}$}} & \multirow{2}{*}{\multicolumn{2}{|c|}{$\begin{array}{l}\text { Controls } \\
(n=436)\end{array}$}} & \multirow[b]{3}{*}{$\mathrm{OR}^{\mathrm{a}}$} & \multirow[b]{3}{*}{$95 \% \mathrm{CI}$} & \multirow{2}{*}{\multicolumn{2}{|c|}{$\begin{array}{l}\text { Cases } \\
(\mathrm{n}=89)\end{array}$}} & \multirow{2}{*}{\multicolumn{2}{|c|}{$\begin{array}{l}\text { Controls } \\
(\mathrm{n}=290)\end{array}$}} & \multirow[b]{3}{*}{$\mathrm{OR}^{\mathrm{a}}$} & \multirow[b]{3}{*}{$95 \% \mathrm{CI}$} \\
\hline & & & & & & & & & & & & \\
\hline & $\mathrm{n}$ & $\%$ & $\mathrm{n}$ & $\%$ & & & $\mathrm{n}$ & $\%$ & $\mathrm{n}$ & $\%$ & & \\
\hline \multicolumn{13}{|l|}{$\begin{array}{l}\text { Energy-adjusted dietary folate } \\
\text { (mcg) }\end{array}$} \\
\hline$\leq 448.57$ & 76 & 37.3 & 145 & 33.3 & 1.00 & Referent & 39 & 43.8 & 97 & 33.4 & 1.00 & Referent \\
\hline$\overline{4} 48.57-561.35$ & 69 & 33.8 & 140 & 32.1 & 1.04 & $0.67,1.61$ & 33 & 37.1 & 101 & 34.8 & 0.79 & $0.43,1.46$ \\
\hline$>561.35$ & 59 & 28.9 & 151 & 34.6 & 0.86 & $0.54,1.38$ & 17 & 19.1 & 92 & 31.7 & 0.45 & $0.22,0.93$ \\
\hline $\mathrm{P}$ trend & & & & & & 0.50 & & & & & & 0.03 \\
\hline $\mathrm{P}$ for folate $\mathrm{x}$ alcohol interaction & & & & & & & & & & & & 0.34 \\
\hline \multicolumn{13}{|l|}{ Energy-adjusted B6 (mg) } \\
\hline$\leq 1.48$ & 60 & 29.4 & 137 & 31.4 & 1.00 & Referent & 35 & 39.3 & 105 & 36.2 & 1.00 & Referent \\
\hline $1.48-1.68$ & 76 & 37.3 & 142 & 32.6 & 1.23 & $0.79,1.90$ & 29 & 32.6 & 100 & 34.5 & 0.95 & $0.51,1.76$ \\
\hline$>1.68$ & 68 & 33.3 & 157 & 36.0 & 0.97 & $0.61,1.54$ & 25 & 28.1 & 85 & 29.3 & 1.06 & $0.54,2.08$ \\
\hline $\mathrm{P}$ trend & & & & & & 0.95 & & & & & & 0.92 \\
\hline $\mathrm{P}$ for $\mathrm{B} 6 \mathrm{x}$ alcohol interaction & & & & & & & & & & & & 0.63 \\
\hline \multicolumn{13}{|l|}{ Energy-adjusted B12 (mcg) } \\
\hline$\leq 4.61$ & 62 & 30.4 & 140 & 32.1 & 1.00 & Referent & 26 & 29.2 & 102 & 35.2 & 1.00 & Referent \\
\hline $4.61-5.76$ & 69 & 33.8 & 146 & 33.5 & 0.92 & $0.59,1.45$ & 33 & 37.1 & 96 & 33.1 & 1.07 & $0.55,2.07$ \\
\hline$>5.76$ & 73 & 35.8 & 150 & 34.4 & 0.96 & $0.61,1.51$ & 30 & 33.7 & 92 & 31.7 & 0.90 & $0.46,1.75$ \\
\hline $\mathrm{P}$ trend & & & & & & 0.94 & & & & & & 0.73 \\
\hline $\mathrm{P}$ for $\mathrm{B} 12 \mathrm{x}$ alcohol interaction & & & & & & & & & & & & 0.86 \\
\hline
\end{tabular}

\footnotetext{
${ }^{a}$ Adjusted for matching variables (child's age, sex, State of residence), child's year of birth, best parental education, child's ethnicity, maternal supplementation with folic acid 3 months before or during pregnancy, maternal supplementation with B6/B12 three months before or during pregnancy.
} 
Table 4: Maternal dietary folate intake and risk of CBT by maternal use of Folic Acid or B6/B12 supplements

\begin{tabular}{|c|c|c|c|c|c|c|c|c|c|c|c|c|}
\hline & \multicolumn{6}{|c|}{ No Folic Acid supplements during pregnancy } & \multicolumn{6}{|c|}{ Any Folic Acid supplements during pregnancy } \\
\hline $\begin{array}{l}\text { Energy-adjusted dietary folate } \\
(\mathrm{mcg})\end{array}$ & \multicolumn{2}{|c|}{$\begin{array}{l}\text { Cases } \\
(\mathrm{n}=97)\end{array}$} & \multicolumn{4}{|c|}{$\begin{array}{l}\text { Controls } \\
(n=194)\end{array}$} & \multicolumn{2}{|c|}{$\begin{array}{l}\text { Cases } \\
(\mathrm{n}=196)\end{array}$} & \multicolumn{4}{|c|}{$\begin{array}{l}\text { Controls } \\
(\mathrm{n}=532)\end{array}$} \\
\hline$\leq 448.57$ & 46 & 47.4 & 91 & 46.9 & 1.00 & Referent & 69 & 35.2 & 151 & 28.4 & 1.00 & Referent \\
\hline $448.57-561.35$ & 31 & 32.0 & 56 & 28.9 & 0.96 & $0.51,1.81$ & 71 & 36.2 & 185 & 34.8 & 0.98 & $0.64,1.51$ \\
\hline$>561.35$ & 20 & 20.6 & 47 & 24.2 & 0.72 & $0.33,1.55$ & 56 & 28.6 & 196 & 36.8 & 0.67 & $0.42,1.06$ \\
\hline $\mathrm{P}$ trend & & & & & & 0.39 & & & & & & 0.09 \\
\hline \multirow[t]{4}{*}{$\begin{array}{l}\text { P for interaction folate } \mathrm{x} \text { folic } \\
\text { acid supplements }\end{array}$} & & & & & & & & & & & & 0.63 \\
\hline & \multicolumn{6}{|c|}{ No B6/B12 supplements during pregnancy } & \multicolumn{6}{|c|}{ Any B6/12 supplements during pregnancy } \\
\hline & \multicolumn{2}{|c|}{$\begin{array}{l}\text { Cases } \\
(\mathrm{n}=205)\end{array}$} & \multicolumn{2}{|c|}{$\begin{array}{l}\text { Controls } \\
(\mathrm{n}=478)\end{array}$} & & & \multicolumn{2}{|c|}{$\begin{array}{l}\text { Cases } \\
(\mathrm{n}=88)\end{array}$} & \multicolumn{4}{|c|}{$\begin{array}{l}\text { Controls } \\
(\mathrm{n}=248)\end{array}$} \\
\hline & $\mathrm{n}$ & $\%$ & $\mathrm{n}$ & $\%$ & $\mathrm{OR}^{\mathrm{a}}$ & $95 \% \mathrm{CI}$ & $\mathrm{n}$ & $\%$ & $\mathrm{n}$ & $\%$ & $\mathrm{OR}^{\mathrm{a}}$ & $95 \% \mathrm{CI}$ \\
\hline $\begin{array}{l}\text { Energy-adjusted dietary folate } \\
\text { (mcg) }\end{array}$ & & & & & & & & & & & & \\
\hline$\leq 448.57$ & 90 & 43.9 & 190 & 39.7 & 1.00 & Referent & 25 & 28.4 & 52 & 21.0 & 1.00 & Referent \\
\hline $448.57-561.35$ & 66 & 32.2 & 145 & 30.3 & 1.04 & $0.68,1.57$ & 36 & 40.9 & 96 & 38.7 & 0.91 & $0.45,1.81$ \\
\hline$>561.35$ & 49 & 23.9 & 143 & 29.9 & 0.83 & $0.52,1.32$ & 27 & 30.7 & 100 & 40.3 & 0.51 & $0.25,1.06$ \\
\hline $\mathrm{P}$ trend & & & & & & 0.47 & & & & & & 0.03 \\
\hline $\mathrm{P}$ for interaction folate $\mathrm{x}$ & & & & & & & & & & & & 0.61 \\
\hline
\end{tabular}

\footnotetext{
a Adjusted for matching variables (child's age, sex, State of residence), child's year of birth, best parental education, child's ethnicity, maternal alcohol during pregnancy.
} 
Table 5: Maternal dietary folate, B6 and B12 during pregnancy and risk of CBT stratified by child's age at diagnosis/recruitment

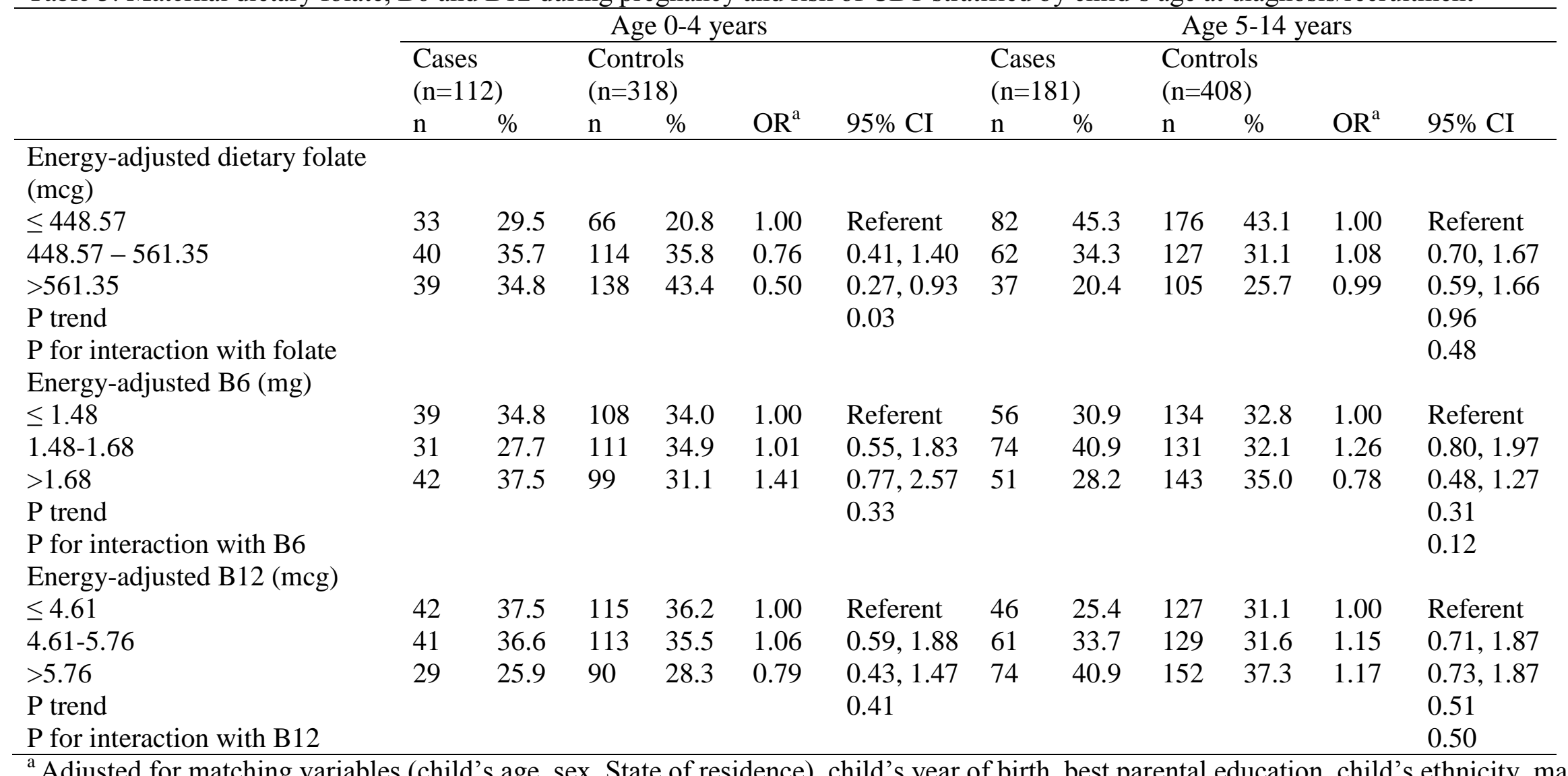

\footnotetext{
${ }^{a}$ Adjusted for matching variables (child's age, sex, State of residence), child's year of birth, best parental education, child's ethnicity, maternal supplementation with folic acid 3 months before or during pregnancy, maternal supplementation with B6/B12 3 months before or during pregnancy.
} 
Supplementary Table 1: Maternal dietary nutrient percentiles ${ }^{\text {a }}$

\begin{tabular}{lllll}
\hline \multirow{2}{*}{ Folate (mcg/day) } & Cases & $25^{\text {th }}$ & 50 th & 75 th \\
\cline { 2 - 5 } & Controls & 387.31 & 485.97 & 594.79 \\
B6 (mg/day) & Cases & 1.26 & 517.54 & 663.76 \\
& Controls & 1.29 & 1.58 & 1.95 \\
B12 (mcg/day) & Cases & 3.78 & 5.08 & 2.02 \\
& Controls & 3.92 & 5.21 & 7.16 \\
&
\end{tabular}

${ }^{\mathrm{a}}$ Values are unadjusted for energy. 
Supplementary Table 2: Maternal dietary folate, B6 and B12 during pregnancy and risk of CBT by tumor subtype

\begin{tabular}{|c|c|c|c|c|c|c|c|c|c|c|c|c|c|c|}
\hline & \multicolumn{2}{|c|}{$\begin{array}{l}\text { Controls } \\
(\mathrm{n}=726)\end{array}$} & \multicolumn{4}{|c|}{$\begin{array}{l}\text { Low grade gliomas } \\
(\mathrm{n}=139)\end{array}$} & \multicolumn{4}{|c|}{$\begin{array}{l}\text { Embryonal Tumors } \\
(\mathrm{n}=70)\end{array}$} & \multicolumn{4}{|c|}{ Other tumors $^{\mathrm{b}}(\mathrm{n}=84)$} \\
\hline & $\mathrm{n}$ & $\%$ & $\mathrm{n}$ & $\%$ & $\mathrm{OR}^{\mathrm{a}}$ & $95 \% \mathrm{CI}$ & $\mathrm{n}$ & $\%$ & $\mathrm{OR}^{\mathrm{a}}$ & $95 \% \mathrm{CI}$ & $\mathrm{n}$ & $\%$ & $\mathrm{OR}^{\mathrm{a}}$ & $95 \% \mathrm{CI}$ \\
\hline \multicolumn{15}{|c|}{$\begin{array}{l}\text { Energy-adjusted dietary } \\
\text { folate }(\mathrm{mcg})\end{array}$} \\
\hline$\leq 448.57$ & 242 & 33.3 & 52 & 37.4 & 1.00 & Referent & 26 & 37.1 & 1.00 & Referent & 37 & 44.0 & 1.00 & Referent \\
\hline $448.57-561.35$ & 241 & 33.2 & 52 & 37.4 & 1.07 & $0.68,1.70$ & 25 & 35.7 & 1.06 & $0.56,2.00$ & 25 & 29.8 & 0.78 & $0.43,1.40$ \\
\hline$>561.35$ & 243 & 33.5 & 35 & 25.2 & 0.68 & $0.41,1.15$ & 19 & 27.1 & 0.78 & $0.38,1.57$ & 22 & 26.2 & 0.64 & $0.34,1.21$ \\
\hline $\mathrm{P}$ trend & & & & & & 0.16 & & & & 0.48 & & & & 0.14 \\
\hline \multicolumn{15}{|c|}{ Energy-adjusted B6 (mg) } \\
\hline$\leq 1.48$ & 242 & 33.3 & 45 & 32.4 & 1.00 & Referent & 20 & 28.6 & 1.00 & Referent & 30 & 35.7 & 1.00 & Referent \\
\hline $1.48-1.68$ & 242 & 33.3 & 48 & 34.5 & 1.13 & $0.71,1.79$ & 32 & 45.7 & 1.62 & $0.87,3.03$ & 25 & 29.8 & 0.85 & $0.47,1.55$ \\
\hline$>1.68$ & 242 & 33.3 & 46 & 33.1 & 1.12 & $0.69,1.83$ & 18 & 25.7 & 1.03 & $0.50,2.13$ & 29 & 34.5 & 0.97 & $0.53,1.76$ \\
\hline $\mathrm{P}$ trend & & & & & & 0.60 & & & & 0.85 & & & & 0.86 \\
\hline \multicolumn{15}{|c|}{ Energy-adjusted B12 (mcg) } \\
\hline$\leq 4.61$ & 242 & 33.3 & 44 & 31.7 & 1.00 & Referent & 11 & 15.7 & 1.00 & Referent & 33 & 39.3 & 1.00 & Referent \\
\hline$\overline{4} .61-5.76$ & 242 & 33.3 & 49 & 35.3 & 0.97 & $0.61,1.57$ & 35 & 50.0 & 2.80 & $1.34,5.85$ & 18 & 21.4 & 0.50 & $0.26,0.94$ \\
\hline$>5.76$ & 242 & 33.3 & 46 & 33.1 & 0.93 & $0.58,1.50$ & 24 & 34.3 & 1.97 & $0.91,4.28$ & 33 & 39.3 & 0.76 & $0.43,1.34$ \\
\hline $\mathrm{P}$ trend & & & & & & 0.76 & & & & 0.12 & & & & 0.32 \\
\hline
\end{tabular}

